\title{
Sterol Regulatory Element-Binding Protein 1
}

National Cancer Institute

\section{Source}

National Cancer Institute. Sterol Regulatory Element-Binding Protein 1. NCI Thesaurus.

Code C105087.

Sterol regulatory element-binding protein 1 (1147 aa, 122 kDa) is encoded by the human SREBF1 gene. This protein is involved in both transcriptional activation and cholesterol homeostasis. 